\title{
Electrocardiographic, echocardiographic, and indirect blood pressure evaluation in dogs subjected to different sedation protocols
}

\author{
Avaliação eletrocardiográfica, ecocardiográfica e de pressão arterial não \\ invasiva de cães submetidos a diferentes protocolos de sedação
}

\author{
Helena Mondardo Cardoso ${ }^{\mathrm{I}^{*}}$ Vanessa Sasso Padilha ${ }^{\mathrm{I}}$ Ronise Tocheto \\ Douglas Regalin ${ }^{I}$ Martielo Ivan Gehrcke ${ }^{I}$ Nilson Oleskovicz ${ }^{I}$
}

\section{ABSTRACT}

The present study aimed to evaluate the effects of different sedation protocols on blood pressure and echocardiographic and electrocardiographic parameters in dogs. In total, 24 male mixed-breed dogs with a mean weight of $9.87 \pm 3.0 \mathrm{~kg}$ were used.Animals were randomly divided into four groups $(n=6)$, which were subjected to sedation using the following protocols: acepromazine $\left(0.05 \mathrm{mgkg}^{-1}\right)$ and butorphanol $\left(0.3 \mathrm{mgkg}^{-1}\right) \quad(A B)$; acepromazine $\left(0.05 \mathrm{mgkg}^{-1}\right)$ and methadone $\left(0.5 \mathrm{mgkg}^{-1}\right)(A M)$; acepromazine $\left(0.03 \mathrm{mgkg}^{-1}\right)$, methadone $\left(0.5 \mathrm{mgkg}^{-1}\right)$, and midazolam $\left(0.3 \mathrm{mgkg}^{-1}\right)(\mathrm{MAM})$; and methadone only $\left(0.5 \mathrm{mgkg}^{-1}\right)(M)$. Indirect blood pressure (BP) measurements and computerized electrocardiography (ECG) and echocardiography (ECO) were performed immediately before the application of the sedation protocol (baseline), and the same evaluations were repeated after 15 minutes. BP decreased in groups AB, MAM, and AM compared to baseline values. Electrocardiographic measurements showed decreased heart rates (HRs) after sedation in all groups, and bradycardia was observed after sedation in two dogs from group $M$ and one animal from group $A M$. The $P$-wave duration increased after sedation in groups $A M$ and $M$. After sedation, no changes in cardiac dimensions were revealed byECO.Fractional shortening (FS) decreased after sedation in the AM group, and dogs from group $A B$ exhibited a smaller decrease in FS compared with the other groups. The cardiac index (CI) was lower in groups $A M$ and $M$ than in the other groups. Animals from group $A B$ were less resistant to examination and exhibited the most favorable sedation scores. It was concluded that the combination of acepromazine and butorphanol was the best sedation protocol for performing echocardiogram measurementsbecause dogs were less resistant to examinations and echocardiographic parameters of FS and CI remained stable.

Key words: cardiac evaluation, butorphanol, acepromazine, methadone, midazolam.

\section{RESUMO}

O objetivo deste estudo foi avaliar os efeitos de diferentes protocolos de sedação sobre a pressão arterial, parâmetros ecocardiográficos e eletrocardiográficos em cães. Foram utilizados 24 cães, machos, SRD, com peso médio de $9,87 \pm 3,0 \mathrm{~kg}$, os quais foram alocados aleatoriamente em quatro grupos $(n=6)$, que foram submetidos à sedação com os protocolos acepromazina $\left(0,05 \mathrm{mg} \mathrm{kg}^{-1}\right)$ e butorfanol $\left(0,3 \mathrm{mgkg}^{-1}\right)(A B)$, acepromazina $\left(0,05 \mathrm{mgkg}^{-1}\right)$ e metadona $\left(0,5 \mathrm{mgkg}^{-1}\right)(\mathrm{AM})$, acepromazina $\left(0,03 \mathrm{mgkg}^{-1}\right)$, metadona $\left(0,5 \mathrm{mgkg}^{-1}\right)$ e midazolam $\left(0,3 \mathrm{mgkg}^{-1}\right)$ (MAM) e metadona isolada $\left(0,5 \mathrm{mgkg}^{-1}\right)(M)$. Foi realizada avaliação da pressão arterial sistólica (PAS) não invasiva, eletrocardiografia computadorizada e ecocardiografia imediatamente antes da aplicação do protocolo de sedação (basal) e repetindose as mesmas avaliações, 15 minutos após. Observou-se redução na PAS nos grupos AB, MAM, AM, em relação ao basal. Na eletrocardiografia, houve redução da FC após sedação em todos grupos, sendo observada bradicardia após sedação em dois cães do grupo $M$ e um animal do grupo AM. A duração da onda $P$ aumentou após sedação nos grupos $A M$ e $M$. Não foram observadas alterações nas dimensões cardiacas, avaliadas pela ecocardiografia, após sedação. A fração de encurtamento (FS) reduziu após sedação no $A M$ e os cães do AB apresentaram menor queda da FS, diferindo dos demais grupos. $O$ indice cardiaco (IC) foi menor no AM e $M$ em relação aos demais. Os animais do grupo AB foram menos resistentes à execução dos exames, apresentando melhores escores de sedação. Concluiu-se que a associação acepromazina e butorfanol foi o melhor protocolo de sedação para realização do ecocardiograma, sendo os cães menos resistentes à execução do exame, mantendo estáveis os parâmetros ecocardiográficos de fração de encurtamento e indice cardiaco.

Palavras-chave: avaliação cardíaca, butorfanol, acepromazina, metadona, midazolam.

\footnotetext{
IUniversidade do Estado se Santa Catarina (UDESC), Av. Madre Benvenuta, 2007, Itacorubi, 88035-001, Florianópolis, SC, Brasil. E-mail: helenamondardo@yahoo.com.br. "Corresponding author.
} 


\section{INTRODUCTION}

In recent decades, it has been noted that the life expectancy of dogs is increasing. Thus, studies investigating cardiovascular changes are even more necessary, given that the incidence of cardiac disease increases with age and that many of these patients require surgical procedures and anesthetic drugs to treat various diseases. Aggressiveness, stress, and agitation of canine patients during diagnostic procedures considerably affects the quality of these examinations. In addition,the use of physical restraintputs the animal at risk, which emphasizes the need toidentify sedation protocols that cause minimalcardiovascular and hemodynamic changes (MONTEIRO, 2011). Although sedation is not always required, it must be used in aggressive and/or stressed animals to promote relaxation and decrease stress (HENIK, 2002). Safe and effective sedatives are required for most diagnostic procedures in veterinary medicine, especially echocardiography (ECO), because they allow the performance of highquality examinations (STEPIEN et al., 1995). Thus, the present study aimed to evaluate, through ECO, electrocardiography (ECG), and blood pressure (BP) measurement, the degrees of sedation and hemodynamic changes that occur in dogs when different sedative protocols are used.

\section{MATERIALS AND METHODS}

In total, 24 male adult dogs aged between one and five yearswith a mean weight of $9.87 \pm 3.0 \mathrm{~kg}$, obtained from regular hospital visits, were used after consent of the owners was obtained. Animals were housed individually in metal cages $\left(1.8 \mathrm{~m}^{3}\right)$. Prior to the beginning of the study, a clinical examination was performed, and blood was collected to perform a complete blood count and serum biochemistry to exclude the presence of disease in patients. Subsequently, animals were subjected to solid and liquid fasting for eight hours prior to the evaluations.

At baseline (M0), five systolic BP measurements were performed using the indirect method (Doppler 841-A, Parks Medical Electronics ${ }^{\circledR}$, Inc. Aloha, Oregon, USA), and the mean value was used as the result, as recommended by BROWN et al. (2007). In addition, ECG and ECO were performed. Exclusion criteria consisted of the presence of cardiac diseases and disorders that might prevent the use of sedation protocols. The ECG examination was performed immediately after the BP was measured via computerized ECG $\left(\right.$ TEB $^{\circledR}$ Digital Electrocardiograph,
ECGPC VET version 6.5) using derivation II, and other derivations were obtained simultaneously to evaluate heart rate (HR), waves, intervals, segment rhythm, and measurements. Echocardiographic examinations were performed using an ECO device (Philips ${ }^{\circledR}$ Healthcare HD15 Ultrasound System) with the animal in the right lateral decubitus position. The transducer, which used a $2-5 \mathrm{MHz}$ frequency, was placed in the right parasternal window, and images from the longitudinal and cross-sectional axes were obtained. The four-chamber and left ventricular outflow tract views were obtained from the long axis, and sections were observed at the apical, papillary, chordal, mitral, and aortic levels in the short axis. Images were initially obtained in B mode to evaluate the anatomical relationships between structures, contractility, morphological and functional aspects of the valves, the presence of regurgitation jets using color Doppler, and pressure gradients of the pulmonary valve. The left atrium and the aorta were measured, and the left atrium/aorta ratio was calculated. Cardiac output (CO) and the ejection fraction (EF) were calculated using the modified Simpson method, as described byBOON (2011). Fractional shortening (FS) was calculated from left ventricular diameter values obtained during diastole and systole, as described by SERRES (2008).

All examinations and sedation evaluations were performed by the same experienced evaluator, who was blind to the treatments used. After the baseline examinations, the animals were randomly divided into four groups consisting of six dogs each: Group AB - acepromazine $\left(0.05 \mathrm{mgkg}^{-1}, \mathrm{IM}\right)$ combined with butorphanol $\left(0.3 \mathrm{mgkg}^{-1}, \mathrm{IM}\right)$; Group AM - acepromazine $\left(0.05 \mathrm{mgkg}^{-1}, \mathrm{IM}\right)$ combined with methadone $\left(0.5 \mathrm{mgkg}^{-1}, \mathrm{IM}\right)$; Group MAM-midazolam $\left(0.3 \mathrm{mgkg}^{-1}, \mathrm{IM}\right)$ combined with acepromazine $\left(0.03 \mathrm{mgkg}^{-1}, \mathrm{IM}\right)$ and methadone $\left(0.5 \mathrm{mgkg}^{-1}\right.$, IM); and Group $\mathrm{M}$-methadone $\left(0.5 \mathrm{mgkg}^{-1}, \mathrm{IM}\right)$. Fifteen minutes after drug administration, degree of sedation was evaluated using the scale described by SAPONARO (2013), in which animals with higher resistance to examinations received lower scores. Then, all the parameters described at baseline were simultaneously measured again. After the last evaluation of parameters, the animals were subjected to local anesthesia, and an orchiectomy was performed according to conventional methods. A statistical analysis was performed using a paired t-test followed by aStudent-Newman-Keuls (SNK) testfor parametric data. A Kruskal-Wallis test followed by a SNKtest and a Wilcoxon test was used for nonparametric data $(\mathrm{P} \leq 0.05)$. 


\section{RESULTS AND DISCUSSION}

In the sedation evaluation, based on the scale proposed by SAPONARO (2013), in which resistance to restraint was evaluated, animals from groups $\mathrm{AM}, \mathrm{MAM}$, and $\mathrm{AB}$ received a higher score after sedation than at baseline, reflecting greater ease during post-treatment examinations. Medicated dogs from group $\mathrm{AB}$ were significantly less resistant to examinations after sedation compared to the other groups. In group M, no changes in the degree of resistance to examinations before and after sedation were observed. MONTEIRO et al. (2009) observed moderate to intense sedation after the use of acepromazine and butorphanol in dogs, similar to the findings observed in the present study.

The mean BP value at baseline was $184 \mathrm{mmHg}$ (Table 1), which differed from the values reported by BROWN et al. (2000) (125mmHg), VACHON et al. (2014) (142 $\mathrm{mmHg})$, and SALLA (2014) (greater than $192 \mathrm{mmHg}$ ), highlighting the variability of the published results. A possible explanation for this discrepancy is the strong influenceof stress levels on BP. The dogs in the present study were visibly stressed and frightenedbecause they did not undergo an adaptation period, which was intentionally omitted to mimic the actual clinical situation. The animals from group $\mathrm{M}$ exhibited significantly higher BP values after sedation than dogs from groups AB, AM, and MAM (Table 1). As there was a significant decrease in $\mathrm{CO}$ values in dogs from group $\mathrm{M}$ (Table 2), it is likely that the maintenance of high BP values occurred due to an increase in pulmonary vascular resistance (PVR), given that this drug increases serum vasopressin concentrations (GAROFALO et al., 2012) and thus increases PVR.

The ECG examinations revealed no differences between the baseline and post-sedation values for P-wave, R-wave, or T-wave amplitude or QRS duration (Table 1). Conversely, it was observed a negative chronotropic effectin all groups, evidenced by a decrease in HR 15 minutes after the application of the sedation protocol (Table 1). This event may be related to the increase in vagal activity promoted by opioids (LAMONT \& MATHEWS, 2013). SEO et al. (2014) also detected a decrease in HR in dogs that were treated with butorphanol only $\left(0.2 \mathrm{mgkg}^{-1}\right.$ IV), similar to our observations in the present study, demonstrating that even a pure non-agonist opioid used alone may cause sufficient vagal stimulation to promote a decrease in HR.In addition, according to SANTOS et al. (2006), when an opioid is combined with a phenothiazine, the interaction between the drugs may cause a greater decrease in HR, which could explain the findings of the present study. Among the dogs from group M, 33.3\% exhibited bradycardia, which was also observed in $16.7 \%$ of dogs from group AM, corroborating the results of MENEGUETI et al. (2014), who found bradycardia in $37.5 \%$ of animals after methadone was administered at the same dose used in the present study. MONTEIRO et al. (2008) observed bradycardia in $16.7 \%$ of animals that received methadone only $\left(0.5 \mathrm{mgkg}^{-1}\right)$ and in $50 \%$ of

Table 1 - Mean values and standard deviations of electrocardiographic and systolic blood pressure parameters in healthy dogs subjected to different sedation protocols.

\begin{tabular}{|c|c|c|c|c|c|c|c|c|}
\hline & M0 & M1 & M0 & M1 & M0 & M1 & M0 & M1 \\
\hline SBP & $187 \pm 18$ & $147 \pm 19 \mathrm{Aa}$ & $180 \pm 39$ & $143.3 \pm 17 \mathrm{Aa}$ & $177.7 \pm 40$ & $135 \pm 18 \mathrm{Aa}$ & $191 \pm 25$ & $176 \pm 18 b$ \\
\hline HR & $124 \pm 15$ & $99 \pm 9 \mathrm{Aa}$ & $120 \pm 20$ & $90 \pm 7 \mathrm{Aac}$ & $120 \pm 25$ & $81 \pm 25 \mathrm{Aac}$ & $107 \pm 16$ & $69 \pm 18 \mathrm{Abc}$ \\
\hline $\mathrm{P}$ & $0.24 \pm 0.07$ & $0.22 \pm 0.03$ & $0.27 \pm 0.05$ & $0.29 \pm 0.06$ & $0.21 \pm 0.05$ & $0.20 \pm 0.07$ & $0.25 \pm 0.09$ & $0.28 \pm 0.08$ \\
\hline $\mathrm{R}$ & $0.92 \pm 0.49$ & $0.90 \pm 0.51$ & $1.43 \pm 0.52$ & $1.39 \pm 0.41$ & $1.18 \pm 0.28$ & $1.15 \pm 0.40$ & $1.10 \pm 0.71$ & $1.56 \pm 0.62$ \\
\hline $\mathrm{T}$ & $0.28 \pm 0.10$ & $0.35 \pm 0.10$ & $0.37 \pm 0.16$ & $0.37 \pm 0.16$ & $0.31 \pm 0.20$ & $0.24 \pm 0.08$ & $0.66 \pm 0.70$ & $0.33 \pm 0.16$ \\
\hline $\mathrm{P}$ & $40 \pm 12$ & $39 \pm 7.8 \mathrm{a}$ & $40 \pm 12$ & $39 \pm 7.9 a$ & $36.5 \pm 3.8$ & $42.7 \pm 7.6 \mathrm{Aa}$ & $46.8 \pm 8.5$ & $55.3 \pm 4.1 \mathrm{Ab}$ \\
\hline PR & $98.7 \pm 9.4$ & $119 \pm 12.3 \mathrm{a}$ & $90.0 \pm 7.0$ & $120.5 \pm 20.5 \mathrm{Aa}$ & $86.7 \pm 11.6$ & $98.8 \pm 13 a$ & $86.7 \pm 8.4$ & $107.2 \pm 16.0 \mathrm{Ab}$ \\
\hline QRS & $47.7 \pm 9.8$ & $44.5 \pm 7.0$ & $51.2 \pm 8.0$ & $49.7 \pm 3.7$ & $48.8 \pm 8.0$ & $47.8 \pm 7.7$ & $51.2 \pm 8.0$ & $54.5 \pm 12.8$ \\
\hline QT & $189 \pm 12.6$ & $224.5 \pm 20.1 \mathrm{~A}$ & $186.7 \pm 14$ & $221.5 \pm 16.5 \mathrm{~A}$ & $179.8 \pm 23.5$ & $205.5 \pm 7.8 \mathrm{~A}$ & $206.7 \pm 18.2$ & $241.2 \pm 31.6 \mathrm{~A}$ \\
\hline
\end{tabular}

Systolic blood pressure (SBP) (mmHg), heart rate (HR) in beats per minute (BPM), P-wave amplitude (P amp) (mV), R-wave amplitude $(\mathrm{mV}), \mathrm{T}$-wave amplitude (mV), P-wave duration (P larg) (ms), PR interval (ms), QRS complex duration (ms), and QT interval (ms). Values at baseline (M0)and 20 minutes after sedation (M1). Acepromazine/butorphanol (AB), acepromazine/midazolam/methadone (MAM), acepromazine/methadone (AM) and methadone (M). Uppercase letters indicate significant differences compared to baseline (M0), t-test. Lowercase letters indicate significant differences between groups, one-way analysis of variance (one-way ANOVA), followed by the Student-Newman-Keuls $(\mathrm{SNK})$ test $(\mathrm{P}<0.05)$. 
Table 2 - Mean values and standard deviations of systolic function indexes measured by echocardiography in healthy dogs subjected to different sedation protocols.

\begin{tabular}{|c|c|c|c|c|c|c|c|c|}
\hline & M0 & M1 & M0 & M1 & M0 & M1 & M0 & M1 \\
\hline HR & $124 \pm 17$ & $99 \pm 9 \mathrm{a}$ & $120 \pm 21$ & $90 \pm 7 \mathrm{Aac}$ & $120 \pm 25$ & $81 \pm 25 \mathrm{Aac}$ & $107 \pm 16$ & $69 \pm 18 \mathrm{Abc}$ \\
\hline FS & $44.5 \pm 8.7$ & $43.0 \pm 3.7 \mathrm{a}$ & $36.7 \pm 4.2$ & $32.4 \pm 3.8 \mathrm{Abc}$ & $37.9 \pm 7.2$ & $29.9 \pm 1.9 \mathrm{Ab}$ & $41.2 \pm 4.9$ & $39.7 \pm 4.9 \mathrm{c}$ \\
\hline $\mathrm{EF}$ & $62.6 \pm 8.5$ & $63.7 \pm 11.6$ & $68.2 \pm 8.1$ & $63.9 \pm 5.4$ & $65.8 \pm 6.9$ & $57.7 \pm 12.8$ & $67.8 \pm 6.6$ & $61.6 \pm 5.0$ \\
\hline FDV & $21.6 \pm 3.3$ & $17.5 \pm 7.5$ & $21.8 \pm 10.8$ & $14.4 \pm 1.9$ & $19.4 \pm 6.4$ & $17.1 \pm 8.9$ & $17.2 \pm 3.8$ & $18.0 \pm 3.3$ \\
\hline FSV & $8.26 \pm 3.9$ & $7.7 \pm 5.4$ & $6.7 \pm 2.7$ & $6.1 \pm 2.5$ & $6.4 \pm 1.8$ & $6.91 \pm 3.9$ & $5.45 \pm 0.6$ & $6.2 \pm 1.7$ \\
\hline SV & $11.1 \pm 3.0$ & $9.8 \pm 4.0$ & $15.1 \pm 7.8$ & $11.0 \pm 4.6$ & $13 \pm 5.1$ & $10.3 \pm 6.0$ & $11.9 \pm 3.3$ & $11.8 \pm 3.4$ \\
\hline $\mathrm{CO}$ & $1.09 \pm 0.3$ & $0.91 \pm 0.4 \mathrm{a}$ & $1.22 \pm 0.3$ & $0.99 \pm 0.5 \mathrm{a}$ & $1.25 \pm 0.4$ & $0.70 \pm 0.3 \mathrm{Ab}$ & $1.18 \pm 0.2$ & $0.74 \pm 0.3 \mathrm{Ab}$ \\
\hline $\mathrm{CI}$ & $2.52 \pm 0.53$ & $2.23 \pm 0.48 \mathrm{a}$ & $2.77 \pm 0.33$ & $2.12 \pm 0.46 \mathrm{a}$ & $2.53 \pm 0.23$ & $1.39 \pm 0.50 \mathrm{Ab}$ & $2.56 \pm 0.33$ & $1.63 \pm 0.45 \mathrm{Aa}$ \\
\hline VmaxAo & $99.8 \pm 23.9$ & $86.5 \pm 13.9$ & $104.6 \pm 20.2$ & $96.7 \pm 31.9$ & $123.5 \pm 17.7$ & $114.0 \pm 27.3$ & $124.8 \pm 23.2$ & $103.2 \pm 31.7$ \\
\hline Vmax PA & $102.7 \pm 12.6$ & $82.9 \pm 16.2$ & $94.7 \pm 10.9$ & $90.5 \pm 21.7$ & $110.8 \pm 26.6$ & $108.2 \pm 17.0 \mathrm{~A}$ & $112.7 \pm 18.1$ & $88.7 \pm 14.8 \mathrm{~A}$ \\
\hline
\end{tabular}

Fractional shortening (FS) (\%), ejection fraction (EF) (\%), final diastolic volume (FDV) (mL), final systolic volume (FSV) (mL), systolic volume $(\mathrm{SV})(\mathrm{mL})$, cardiac output $(\mathrm{CO})\left(\mathrm{Lmin}^{-1}\right)$, cardiac index $(\mathrm{CI})\left(\mathrm{L} / \mathrm{min} / \mathrm{m}^{2}\right)$, maximum aortic flow systolic peak velocity $(\mathrm{VmaxAo})$ $(\mathrm{cm} / \mathrm{s})$, maximum pulmonary artery flow systolic peak velocity (Vmax PA) $\left(\mathrm{cms}^{-1}\right)$ at baseline (M0) and during sedation (M1). Acepromazine/butorphanol (AB), acepromazine/midazolam/methadone (MAM), acepromazine/methadone (AM), and methadone (M). Uppercase letters indicate significant differences compared to baseline (M0) values, t-test.Lowercase letters indicate significant differences between groups, analysis of variance (one-way ANOVA), followed by the Student-Newman-Keuls $(\mathrm{SNK})$ test $(\mathrm{P}<0.05)$.

animals that received both acepromazine $\left(0.1 \mathrm{mgkg}^{-1}\right)$ and methadone $\left(0.5 \mathrm{mgkg}^{-1}\right)$. CREDIE et al. (2010) observed bradycardia and sinus arrest in two animals that received methadone $\left(0.5 \mathrm{mgkg}^{-1}\right.$ and $\left.1 \mathrm{mgkg}^{-1}\right)$.

In dogs from group $\mathrm{M}$, the $\mathrm{P}$-wave duration was increased after sedation. Briefly, the P-waverepresents atrial electrical conduction; therefore, changes in its duration may indicate an overload of the left atrium (CAMACHO et al., 1998). However, this hypothesis was discarded because the echocardiographic evaluation did not show an increase in the left atrium. Conversely, a possible explanation for this change is that opioids, such as methadone, also affect the cardiac calcium and potassium channels, prolonging the action potential and; therefore, increase the cardiac conduction time.

In groups $\mathrm{M}$ and MAM, the atrioventricular electric conduction time (PR interval) was greater after sedation, which was expected because this variable is inversely proportional to HR. According to SANTOS et al. (2004), a longer PR intervaloccurs as a compensation mechanism for decreased HR to allow greater ventricular filling and maintain $\mathrm{CO}$ withinnormal values. In the present study, all the groups exhibited a significant increase in the QT interval duration, which is consistent with data obtained by SANTOS et al. (2004) and MENEGUETI et al. (2014); however, values remained within the reference interval $(0.15-0.25$ seconds). A possible explanation for this finding is the delay in ventricular repolarization produced by opioids (MENEGUETI et al., 2014; STAIKOU et al., 2014).
No significant differences were observed in cardiac and aortic dimensions, FS, ejection fraction (EF), final diastolic volume (FDV), final systolic volume (FSV),or systolic volume (SV) among the different groups and time points (Table 2 and Table 3). Dogs from group $\mathrm{AB}$ exhibited a slight decrease $(0.04 \%)$ in FS values after sedation, which was significantly different from the values of the other groups (Table 2). Three factors primarily affect FS: preload, afterload, and contractility. Therefore, potential acepromazine effects, including promoting a decrease in the pre- and afterload due to alpha-1-adrenergic blockade and consequent peripheral vasodilation (NOGUEIRA et al., 2012), did not promote significant decreases in HR when acepromazine was combined with butorphanol. In dogs from group AM, there was a significant decrease in FS after sedation. Because FS is influenced by several previously mentioned factors, it can be inferred that methadone likely caused an increase in the afterload, given that methadone increases the release of vasopressin (INGVASTLARSSON et al., 2007). In addition, a compensatory increase in contractility, as a response to the increased afterload, did not occur due to the dopamine blockade by acepromazine, which culminated in a negative inotropic effect, decreasing contractility. Therefore, both factors contributed to this important decrease in FS. In contrast, in dogs from the MAM group, this decrease was not observed, although these animals were treated with the same dose of methadone. Therefore, the lowest dose of acepromazine used did not promote an inotropic effect sufficient to decrease FS. 
Table 3 - Mean values and standard deviations of Doppler echocardiographic parameters obtained in healthy dogs subjected to different sedation protocols.

\begin{tabular}{|c|c|c|c|c|c|c|c|c|}
\hline & M0 & M1 & M0 & M1 & M0 & M1 & M0 & M1 \\
\hline Ao & $1.64 \pm 0.21$ & $1.66 \pm 0.28$ & $1.79 \pm 0.28$ & $1.71 \pm 0.20$ & $1.78 \pm 0.33$ & $1.72 \pm 0.28$ & $1.67 \pm 0.21$ & $1.70 \pm 0.18$ \\
\hline $\mathrm{AE}$ & $1.83 \pm 0.16$ & $1.83 \pm 0.28$ & $1.99 \pm 0.30$ & $1.83 \pm 0.32$ & $1.90 \pm 0.52$ & $1.85 \pm 0.24$ & $1.78 \pm 0.30$ & $1.80 \pm 0.24$ \\
\hline LA/Ao & $1.12 \pm 0.09$ & $1.10 \pm 0.08$ & $1.12 \pm 0.09$ & $1.06 \pm 0.08$ & $1.13 \pm 0.37$ & $1.10 \pm 0.07$ & $1.06 \pm 0.11$ & $1.06 \pm 0.08$ \\
\hline IRVDd & $0.48 \pm 0.08$ & $0.51 \pm 0.13$ & $0.45 \pm 0.15$ & $0.61 \pm 0.13$ & $0.54 \pm 0.12$ & $0.61 \pm 0.16$ & $0.51 \pm 0.19$ & $0.67 \pm 0.15$ \\
\hline IVSTd & $0.65 \pm 0.16$ & $0.72 \pm 0.22$ & $0.69 \pm 0.14$ & $0.89 \pm 0.46$ & $0.70 \pm 0.13$ & $0.72 \pm 0.17$ & $0.86 \pm 0.23$ & $0.87 \pm 0.26$ \\
\hline ILVDd & $2.90 \pm 0.62$ & $2.68 \pm 0.60$ & $2.98 \pm 1.05$ & $2.59 \pm 0.37$ & $3.09 \pm 0.66$ & $2.89 \pm 0.60$ & $2.76 \pm 0.74$ & $2.9 \pm 0.43$ \\
\hline LVFWTd & $0.72 \pm 0.07$ & $0.78 \pm 0.16$ & $1.07 \pm 0.40$ & $0.73 \pm 0.10$ & $0.87 \pm 0.20$ & $0.76 \pm 0.04$ & $0.80 \pm 0.19$ & $0.87 \pm 0.13$ \\
\hline ILVDs & $1.60 \pm 0.37$ & $1.53 \pm 0.36$ & $1.88 \pm 0.62$ & $1.76 \pm 0.27$ & $1.90 \pm 0.45$ & $2.02 \pm 0.44$ & $1.60 \pm 0.37$ & $1.75 \pm 0.27$ \\
\hline $\mathrm{E} / \mathrm{A}$ & $1.67 \pm 0.17$ & $1.91 \pm 0.33$ & $1.59 \pm 0.30$ & $1.72 \pm 0.13$ & $1.57 \pm 0.29$ & $1.91 \pm 0.26$ & $1.81 \pm 0.22$ & $1.76 \pm 0.49$ \\
\hline Lat E'/A' & $1.85 \pm 0.51$ & $1.73 \pm 0.45$ & $1.61 \pm 0.24$ & $2.05 \pm 0.44$ & $1.90 \pm 0.38$ & $2.30 \pm 0.46$ & $1.58 \pm 1.17$ & $2.10 \pm 0.43$ \\
\hline Med E'/A' & $1.54 \pm 0.56$ & $1.52 \pm 0.51$ & $1.59 \pm 0.25$ & $2.06 \pm 0.55$ & $1.67 \pm 0.38$ & $1.98 \pm 0.44$ & $1.62 \pm 0.20$ & $1.98 \pm 0.54$ \\
\hline $\mathrm{E} / \mathrm{A}$ & $1.67 \pm 0.17$ & $1.91 \pm 0.33$ & $1.59 \pm 0.30$ & $1.72 \pm 0.13$ & $1.57 \pm 0.29$ & $1.91 \pm 0.26$ & $1.81 \pm 0.22$ & $1.76 \pm 0.49$ \\
\hline IVRT & $0.059 \pm 0.007$ & $0.061 \pm 0.011$ & $0.061 \pm 0.008$ & $0.063 \pm 0.004$ & $0.052 \pm 0.010$ & $0.062 \pm 0.012$ & $0.057 \pm 0.015$ & $0.069 \pm 0.010$ \\
\hline
\end{tabular}

Aortic diameter (Ao) $(\mathrm{cm})$, left atrium diameter $(\mathrm{LA})(\mathrm{cm})$, left atrium and aorta ratio LA/Ao; internal right ventricular diameter during diastole $(I R V D d)(\mathrm{cm})$, interventricular septum thickness during diastole (IVSTd) $(\mathrm{cm})$, internal left ventricular diameter during diastole (ILVDd) $(\mathrm{cm})$, left ventricular free wall thickness during diastole (LVFWTd) $(\mathrm{cm})$, internal left ventricular diameter during systole (ILVDs) $(\mathrm{cm})$, ratio between the peak velocity of the $\mathrm{E}$ and A waves of the mitral valve (E/A), isovolumic relaxation time (IVRT), ratio between the peak velocity of the lateral E' and A' waves (lat E'/A'), ratio between the peak velocity of the medial E' and A' waves (med E'/A') at baseline (M0) and during sedation (M1).Acepromazine/butorphanol (AB), acepromazine/midazolam/methadone (MAM), acepromazine/methadone (AM), and methadone (M).

In groups $\mathrm{AM}$ and $\mathrm{M}$, there was a significant decrease in cardiac index $(\mathrm{CI})$ values $(36 \%$ and $45 \%$, respectively) after sedation; these decreases were significantly different from those of dogs in groups MAM and AB (Table 2). The likely explanation for this result is that a significant decrease in HR was also observed in dogs from these groups with the concomitant maintenance of SV values, which directly affects CI values. GAROFALO et al. (2012) also observed decreases in HR and CI after methadone was administered, corroborating the findings of the present study. Regarding the parameters associated with diastolic function (E/A ratio, IVRT, E'- wave, and A 'wave), no significant differences were observed among the groups and time points (Table 3 ).

Most patients who are referred for echocardiographic examinations have suspected heart disease or are elderly. Therefore, a limitation of the present study is that we cannot directly apply the conclusions obtained here because only healthy animals were used.

\section{BIOETHICS AND BIOSSECURITY COMMITTE APPROVAL}

This study was approved by the Ethics and Animal Welfare Committee (Comitê de Ética e Bem Estar Animal CETEA) of the originating institution, protocol number 1.45.13.

\section{CONCLUSION}

The administration of acepromazine combined with butorphanol produces a better degree of sedation for echocardiographic examinations and maintains the stability of the hemodynamic parameters of contractility and CI, in addition to not inducing arrhythmia or causing significant changes in electrocardiographic or BP measures.

\section{REFERENCES}

BOON, J.A. Veterinary echocardiography. 2.ed. Oxford: WileyBlackwell, 2011. 480p.

BROWN, S.A. et al. Diagnosis of systemic hypertension in dogs and cats. In: BONAGURA, J.D. Small Animal Practice. Philadelphia: Saunders, 2000. p.835-838.

BROWN, S. et al. Guidelines for the identification, evaluation, and management of systemic hypertension in dogs and cats. Journal of Veterinary Internal Medicine, v.21, p.542558, 2007.Available from: <http://onlinelibrary.wiley.com/ doi/10.1111/j.1939-1676.2007.tb03005.x/pdf>. Accessed: Nov. 20, 2014. doi: 10.1111/j.1939-1676.2007.tb03005.

CAMACHO, A.A.A. et al. Eletrocardiografia na medicina veterinária. Revista de educação continuada do CRMV-SP, São Paulo, v.1, n.1, p.54-57, 1998. Available from: <http://revistas.bvs-vet.org.br/recmvz/ article/view/3396/2603>. Accessed: Nov. 23, 2014.

CREDIE, R.G. et al. Effects of methadone on the minimum alveolar concentration of isoflurane in dogs. Veterinary Anaesthesia and Analgesia, v.37, p.240-249, 2010.Available 
from: <http://onlinelibrary.wiley.com/doi/10.1111/j.14672995.2010.00528.x/abstract; jsessionid=3B1810523 C09FF 044979D8A97E68516E.f04t01>. Accessed: Oct. 22, 2014. doi: $10.1111 /$ j.1467-2995.2010.00528.x.

GAROFALO, N.A. et al. Cardiorespiratory and neuroendocrine changes induced by methadone in conscious and in isofluraneanaesthetised dogs. Veterinary Journal, v.194, p.398404, 2012. Available from: <http://www.sciencedirect.com/ science/article/pii/S1090023312001293>. Accessed:Oct. 23, 2014. doi:10.1016/j.tvj1.2012.03.019.

HENIK, R.A. Ecocardiografia e ultra-som Doppler. In: TILLEY, L.P.; GOODWIN, J.K. Manual de cardiologia para cães e gatos. 3.ed. São Paulo: Roca, 2002. p.67-94.

INGVAST-LARSSON, C. et al. Clinical pharmacology of buprenorphine in healthy, lactating goats. Journal of Veterinary Pharmacology and Therapeutics, v.30, p.249-256, 2007. Available from: <http://onlinelibrary.wiley.com/doi/10.1111/ j.1365-885.2007.00858.x/pdf>. Accessed: Oct. 23, 2014. doi: 10.1111/j.1365-2885.2007.00858.x.

LAMONT, L.A.; MATHEWS, K.A. Opióides, anti-inflamatórios não esteroidais e analgésicos adjuvantes. In: TRANQUILI, W.L. Anestesiologia e analgesia veterinária. 4.ed. São Paulo: Roca, 2013. Cap.10, p. 270-304.

MENEGUETI, T.M. et al. Eletrocardio graphice valution of the degree of sedation and the isolated use of metadhone in healthy dogs. Veterinary Anaesthesia and Analgesia, v.41, p.97-104, 2014. Available from: <http://onlinelibrary.wiley.com/doi/10.1111/ vaa.12086/pdf>. Accessed: Oct. 22, 2014. doi: 10.1111/vaa.12086.

MONTEIRO, E.R. et al. Effects of methadone, alone or in combination with acepromazine or xylazine, on sedation and physiologic values in dogs. Veterinary Anaesthesia and Analgesia, v.35, p.519-527, 2008. Available from: $<$ http://onlinelibrary.wiley.com/doi/10.1111/j.14672995.2008.00412.x/abstract;jsessionid=CBD41DA F9D1C4EB6411F7604BFB42A22.f04t01>. Accessed: Nov. 23, 2014. doi: 10.1111/j.1467-299 5.2008.00412.x.

MONTEIRO, E.R. et al. Comparative study on the sedative effects of morphine, methadone, butorphanol or tramadol, in combination with acepromazine, in dogs. Veterinary Anaesthesia and Analgesia, v.36, p.25-33, 2009. Available from: <http://onlinelibrary.wiley.com/ doi/10.1111/j.1467-2995.2008.00424.x/abstract;jsessionid=FB 1419135271A898ADE23C324E8231DB.f01t01>. Accessed: Nov. 10, 2014. doi: 10.1111/j.1467-2995.2008.00424.x.

NOGUEIRA, R.B. et al. Effects of sedation with acepromazine maleate and buprenorphine hydrochloride on femoral artery blood flow in healthy dogs. Research in Veterinary Science, v.93, n.1, p.989-992, 2012. Available from: <http://www.sciencedirect.com/ science/article/pii/S0034528811003845>. Accessed: Nov. 09 , 2014. doi: 10.1016/j.rvsc.2011.10.004.
SALLA, K. et al. A comparison in dogs of medetomidine, with or without MK-467, and the combination acepromazinebutorphanol as premedication prior to anaesthesia induced by propofol and maintained with isoflurane. Veterinary Anaesthesia and Analgesia, v.41, p.163-173, 2014. Available from: <http:// onlinelibrary.wiley.com/doi/10.1111/vaa.12094/pdf $>$. Accessed: Nov. 09, 2014. doi: 10.1111/vaa.12094.

SANTOS, P.S.P. et al. Efeitos cardiorrespiratórios do butorfanol em cães pré-tratados ou não pela levomepromazina. Ciência Rural, v.36, n.5, p.1429-1435, 2006. Available from: $<$ http:// scholar.google.com.br/scholar? $\mathrm{q}=$ Efeitos \pm cardiorrespirat $\% \mathrm{C} 3 \% \mathrm{~B}$ 3rios \pm do \pm butorfanol \pm em $\pm \mathrm{c} \% \mathrm{C} 3 \% \mathrm{~A} 3 \mathrm{es} \pm \mathrm{pr} \% \mathrm{C} 3 \% \mathrm{~A} 9$-tratados $\pm \mathrm{o}$ $\mathrm{u} \pm \mathrm{n} \% \mathrm{C} 3 \% \mathrm{~A} 3 \mathrm{o} \pm$ pela \pm levomepromazina\& $\mathrm{btnG}=\& \mathrm{hl}=$ pt-BR\&as_ $\mathrm{sdt}=0 \% 2 \mathrm{C} 5 \&$ as_vis $=1>$. Accessed: Nov. 09, 2014.

SAPONARO, V. et al. Echocardiographic evaluation of the cardiovascular effects of medetomidine, acepromazine and their combination in healthy dogs. Research in Veterinary Science, v.95, p.687-692, 2013. Available from: <http://dx.doi. org/10.1016/j.rvsc.2013.03.022>. Accessed: Nov. 17, 2014.doi: 10.1016/j.rvsc.2013.03.022.

SEO, J.I. et al. Cardiopulmonary and anesthetic effects of the combination of butorphanol, midazolam and alfaxalone in Beagle dogs. Veterinary Anaesthesiaand Analgesia, v.?,n.?, p.?-?, 2014. Disponível em: <http://onlinelibrary. wiley.com/doi/10.1111/vaa.12223/pdf>. Accessed: Nov. 18, 2014. doi: 10.1111/vaa.12223.

SERRES, F. et al. Comparison of 3 ultrasound methods for quantifying left ventricular systolic function: correlation with disease severity and prognostic value in dogs with mitral valve disease. Journal of Veterinary Internal Medicine, v.22, p.566-577, 2008. Available from: <http://onlinelibrary.wiley.com/doi/10.1111/j.19391676.2008.0097.x/abstract; jsessionid=0798DDCEA06A 42DD35A66CA6B21D79BC.f03t02>. Accessed: Jul. 13, 2015. doi: 10.1111/j.1939-1676.2008.0097.x.

STAIKOU, C.et al. Impact of anaesthetic drugs and adjuvants on ECG markers of toarsadogenicity. British Journal of Anaesthesia, v.112, n.2, p.217-230, 2014. Available from: <http://bja. oxfordjournals.org/content/112/2/217.full.pdf \pm html $>$. Accessed: Oct. 15, 2014. doi: 10.1093/bja/aet412.

STEPIEN, R.L. et al. Cardiorespiratory effects of acepromazine maleate and buprenorphine hydrochloride in clinically normal dogs. American Journal Veterinary Research, v.56, n.1, p.78-84, 1995. Available from: <http:/www.ncbi.nlm.nih.gov/ pubmed/7695154>. Accessed: Jul. 13, 2015.

VACHON, C. et al. Evaluation of oscillometric and Doppler ultrasonic devices for blood pressure measurements in anesthetized and conscious dogs. Research in Veterinary Science, v.96, n.1, p.1-7, 2014. Available from: <http://www. sciencedirect.com/science/article/pii/S0034528814001507>. Accessed: Oct. 24, 2014. doi: 10.1016/j.rvsc.2014.05.003. 